\title{
COXEN Score 7
}

National Cancer Institute

\section{Source}

National Cancer Institute. COXEN Score 7. NCI Thesaurus. Code C128204.

A score of 7 on the COXEN Sensitivity Scale. 